\title{
Variations in Offshore Suspended Sediment Characteristics and Effects of Ocean Dynamics: The Case of Terrebonne Bay, Northern Gulf of Mexico
}

\author{
Biyun Guo ${ }^{1,2^{*}}$ and Mantravadi Venkata Subrahmanyam ${ }^{1 * *}$ \\ ${ }^{1}$ Marine Science and Technology College, Zhejiang Ocean University, Zhoushan, Zhejiang 316022, P.R. China \\ ${ }^{2}$ State Key Laboratory of Plateau Ecology and Agriculture, Qinghai University, \\ Xining, Qinghai 810016, P.R. China
}

(Received June 12, 2020; accepted October 30, 2020)

Keywords: satellite imagery, total suspended sediment concentration, rainfall, wave period, wind speed, wind direction

Marine dynamics plays an important role in understanding the variations in offshore suspended sediment distribution and transport direction. In this study, variations in total suspended sediment concentration (TSSC) over Terrebonne Bay in the northern Gulf of Mexico were investigated by using remote sensing technology in relation to ocean-atmospheric dynamics. The terrestrial rainfall/runoff and river discharge in the lower Mississippi River estuarine area during the study period played an important role in the surface TSSC distribution. In most cases, the wave period and wind speed affected TSSC and its distribution. There was an inverse relationship between TSSC and wave period, but wind speed exhibited a positive relationship with TSSC distribution; however, there was a slight delay. The southeast (onshore) wind accounted for $57.0 \%$ of the wind direction over the study area and played a major role in the control of the surface sediment concentration in Terrebonne Bay in July 2010. The onshore wind lifted the underlying sediment, increasing the TSSC at the sea surface. The maximum TSSC was $1056.47 \mathrm{mg} / 1$ in the southeast direction $\left(96.75^{\circ}\right.$, onshore) on July 1. Other higher TSSCs were also observed in the southeast wind direction: $996.38,820.55$, and $605.27 \mathrm{mg} / 1$ with wind directions of $99.63,127.33$, and $120.17^{\circ}$ on 2, 5, and 6 July 2010, respectively. The correlation coefficients between TSSC and wave period and wind speed were 0.45 and 0.47 , respectively (significant level of $99 \%$ ). The sediment concentration in the coastal area was related to coastal erosion and river discharge. The sediment transport not only was related to the physical properties of the sediment, but also depended on the flow velocity. The wind-driven flow field is one of the main factors that drive sediment transport. The sediments in the estuary and bay have many similarities in their dynamic environment and development evolution. The study of the dynamic response of offshore sediments is a supplement to the theory of sediment transport in the estuary and coastal zones. The study of the relationship between ocean dynamics and sediment transport can provide a reference for the site selection of offshore engineering structures.

\footnotetext{
*Corresponding author: e-mail: biyunguo@163.com

** Corresponding author: e-mail: mvsm.au@gmail.com https://doi.org/10.18494/SAM.2020.2958
} 


\section{Introduction}

The northern part of the Gulf of Mexico has the largest river system in North America and is economically important because of its diverse ecosystem. Mississippi and Atchafalaya rivers feed fresh water plumes to the Gulf of Mexico through the Mobile Bay estuary. ${ }^{(1,2)}$ The Gulf shore has a complex geometry, and morphological changes in this area are driven by spatial and temporal gradients of sediment transition. Owing to terrestrial runoff, the sediment that eroded over the land was deposited at the continental margin or transported to coastal water. The sediment discharge into the sea is affected by rainfall, river runoff, and sediment concentration. Sediment particles are carried to the marine system by rivers and dispersed by the combined action of waves and current, which are governed by the local hydrodynamics, bottom morphology, and weather system. The particle distribution is subsequently affected by sediment transport, deposition, and resuspension cycles over the continental shelf and slope. ${ }^{(3)}$

Usually, suspended sediment transition and oceanic environmental dynamic factors are important for coastal and offshore structural design. Wave and wind dynamics are the most important in sediment resuspension in coastal water. The wave-induced bottom shear stress is the dominant force revealed by field observation. ${ }^{(4-6)}$ Tidal current is typically not strong enough in a microtidal estuarine environment to contribute significantly to sediment resuspension. ${ }^{(7-9)}$ Sediment transport and suspended sediment concentrations are strongly dependent on the tide. Tidal current is responsible for the transport and redistribution of suspended sediment. ${ }^{(4,10,11)}$ In the nearshore zone, oceanic forces drive sediment transport in both cross- and longshore directions, thereby generating variations in foreshore profile. ${ }^{(12-14)} \mathrm{A}$ strong relationship between wave power and shoreline retreat has been presented. ${ }^{(15,16)}$ Wind, sea, and swell waves are responsible mostly for local erosion and sediment resuspension, whereas tidal and wind-driven currents are responsible mostly for transporting the material from the source.

Terrebonne Bay is located in the northern Gulf of Mexico and, owing to continuous sediment delivery, has migrated landward an average of nearly $17 \mathrm{~km}(17000 \mathrm{~m})$ from 1932 to 2010 (78 years), which corresponds to a migration rate of $0.22 \mathrm{~km} /$ year $(218 / \mathrm{m}) .{ }^{(17)}$ Wind waves in Terrebonne Bay play an important role in turbidity changes because they are responsible for the erosion of tidal flats and marsh edges, and hence the resuspension of the freshly deposited material in the bay. ${ }^{(18)}$

Suspended sediment affects the optical characteristics of water, such as transparency and color, as well as the evolution of the estuary and coast. The amount of sediment in water directly affects the reflectance of solar radiation; the more sediment in suspension, the greater the reflectance. ${ }^{(19-21)}$ However, the relationship between total suspended sediment and reflectance also depends on the mineralogy, color, and size of the sediment. ${ }^{(22-24)}$ Studies have revealed that there is a certain correlation between the spectral value of different bands of remote sensing images and the suspended sediment concentration. Since the 1970s, remote sensing has been used to quantify the total suspended sediment concentration (TSSC) over the surface water. ${ }^{(19)}$ A previous study in the Gulf of Mexico has revealed a strong statistical relationship between TSSC and reflectance. ${ }^{(25)}$ 
The study of the distribution characteristics of TSSC in the sea is helpful in analyzing coastal siltation and erosion. Because of the limited observation technology, the research on the spatial characteristic of suspended sediment transfer, the transport mechanism, and the sediment fluxes is constrained. The impact of the oceanic dynamic factors on sediment transport and sedimentation, shoreline erosion, and deposition has yet to be known.

In recent years, because of the impact of climate change and human activities, changes in the distribution of suspended sediment and shoreline erosion in Terrebonne Bay as a result of changes in the flow of the Mississippi River have become issues of concern. For the monitoring of TSSC in a wide sea area range, the remote sensing technology and in situ measurement of TSSC can be used to establish an inversion model ${ }^{(20,26)}$ and can help us to clarify this issue.

\section{Study Site: Terrebonne Bay}

Terrebonne Bay, situated to the west of the Mississippi River in southern Louisiana in the northern Gulf of Mexico, USA, has one of the highest wetland loss rates among Louisianian estuaries. ${ }^{(27,28)}$ The bay is approximately $40 \mathrm{~km}$ wide and spans $25 \mathrm{~km}$ from the northernmost marsh to the barrier island that separates it from the Gulf of Mexico. ${ }^{(29)}$ Terrebonne Bay was a delta plain of the Mississippi River 3000 to 4000 years ago and its main distributary during the last 1000 years $^{(7)}$ between the Atchafalaya delta and the Mississippi River bird-foot delta. Because of its position on the rapidly eroding coast, the turbidity and sediment changes in the area originate from bay bed erosion. The erosion of the surrounding wetlands is caused by wave activity and the passage of cold fronts and storms. ${ }^{(30)}$ As a result of the continuous erosion, Terrebonne Bay has suffered tremendous wetland loss. There is a method to compare $50 \% \mathrm{~L}: \mathrm{W}$ isopleths ( $\mathrm{L}: \mathrm{W}$ ratio is the ratio of land to water) across the Terrebonne and Atchafalaya Basins to test landscape behaviour over the last 60 years to estimate delta instability in coastal deltaic basins as a function of sediment supply reduction from river flooding. In the upper Terrebonne Bay, the largest landward migration of the $50 \% \mathrm{~L}: \mathrm{W}$ ratio isopleth occurred, the estimated wave power increased by $50-100 \%$ from 1932 to 2010 . The maximum storm-surge height also increased with the changes in topographic conditions owing to landward migration. ${ }^{(17)}$

To analyze the nearshore TSSC, field measurements were carried out at Terrebonne Bay in July 2010, to better understand the marine dynamic factors that play roles in the estuarine and coastal evolution process. The site is south of Terrebonne Bay, Louisiana (Fig. 1), at CSI 6 (28 $52^{\circ}$ $\mathrm{N}$ and $-90^{\circ} 29^{\prime} \mathrm{W}$, the red dot in Fig. 1), a Wave-Current-surge Information System (WAVCIS) monitoring station, Coastal Ocean Estuarine Dynamics Lab, Louisiana State University.

\section{Materials and Methods}

\subsection{Collection of field data}

The field data were obtained from WAVCIS, which is a scientifically designed regional online ocean observation system near the Louisiana coast. The observation system automatically measures offshore area and oceanographic and meteorologic data. The optimal operation of this observation system is supported by the experts at the Coastal Ocean Estuarine 

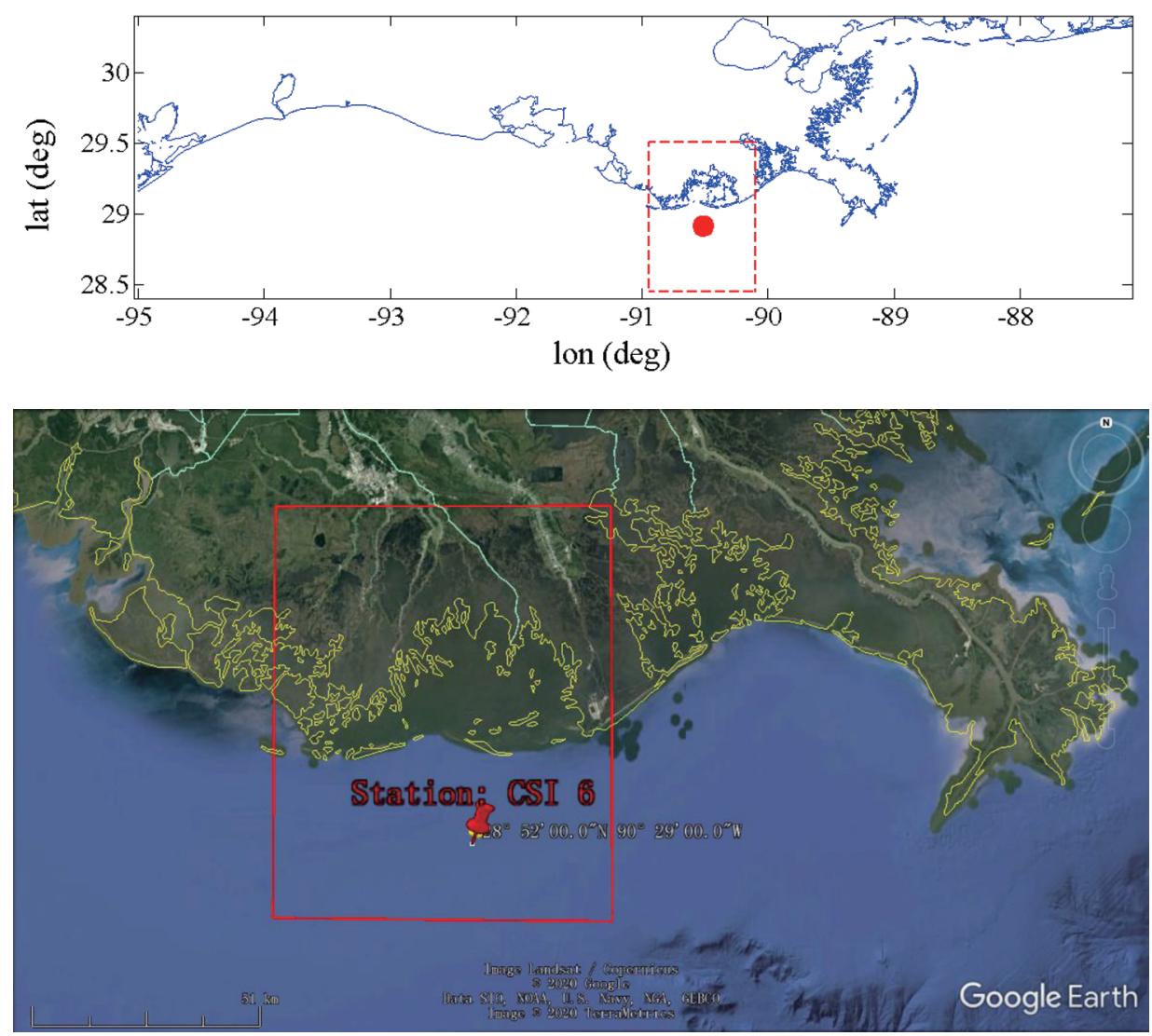

Fig. 1. (Color online) Location map of study area in northern Gulf of Mexico.

Dynamics Lab at Louisiana State University, and the data are freely available. There are thirteen WAVCIS stations in this area; the research area is located at the CSI 6 station, which is nearly offshore and is located $20 \mathrm{~km}$ south of Timbalier Island of Louisiana.

In situ measurements of hydraulic variables and meteorologic data were obtained throughout the study area at the fixed station (WAVCIS CSI 6) in July 2010 (Fig. 1). At the station, data are automatically collected using a state-of-the-art sensor package that includes instruments for measuring the meteorologic and oceanographic data above and below the sea surface. Continuous information about the wave condition (wave period) was obtained from the Acoustic Doppler Current Profile (ADCP) produced by RD Instrument Inc. The ADCP was mounted on a bottom platform with an upward-looking configuration. The wind speed and wind direction were collected at $1 \mathrm{~h}$ intervals using a Hobo automated weather station at a height of $2 \mathrm{~m}$ throughout July in 2010. Figure 2 illustrates the variations in wave period, wind speed, and wind direction in July 2010.

The rainfall data used in this study were obtained from the Global Precipitation Climatology Project (GPCP) precipitation dataset over a study area located downstream of the Mississippi River $\left(29^{\circ} 55^{\prime} 01^{\prime \prime} \mathrm{N},-90^{\circ} 25^{\prime} 57^{\prime}\right.$ ' W). The GPCP v1.3 daily precipitation data used for this study were obtained during the period from June 15 to August 10, 2010 (see Fig. 3). 

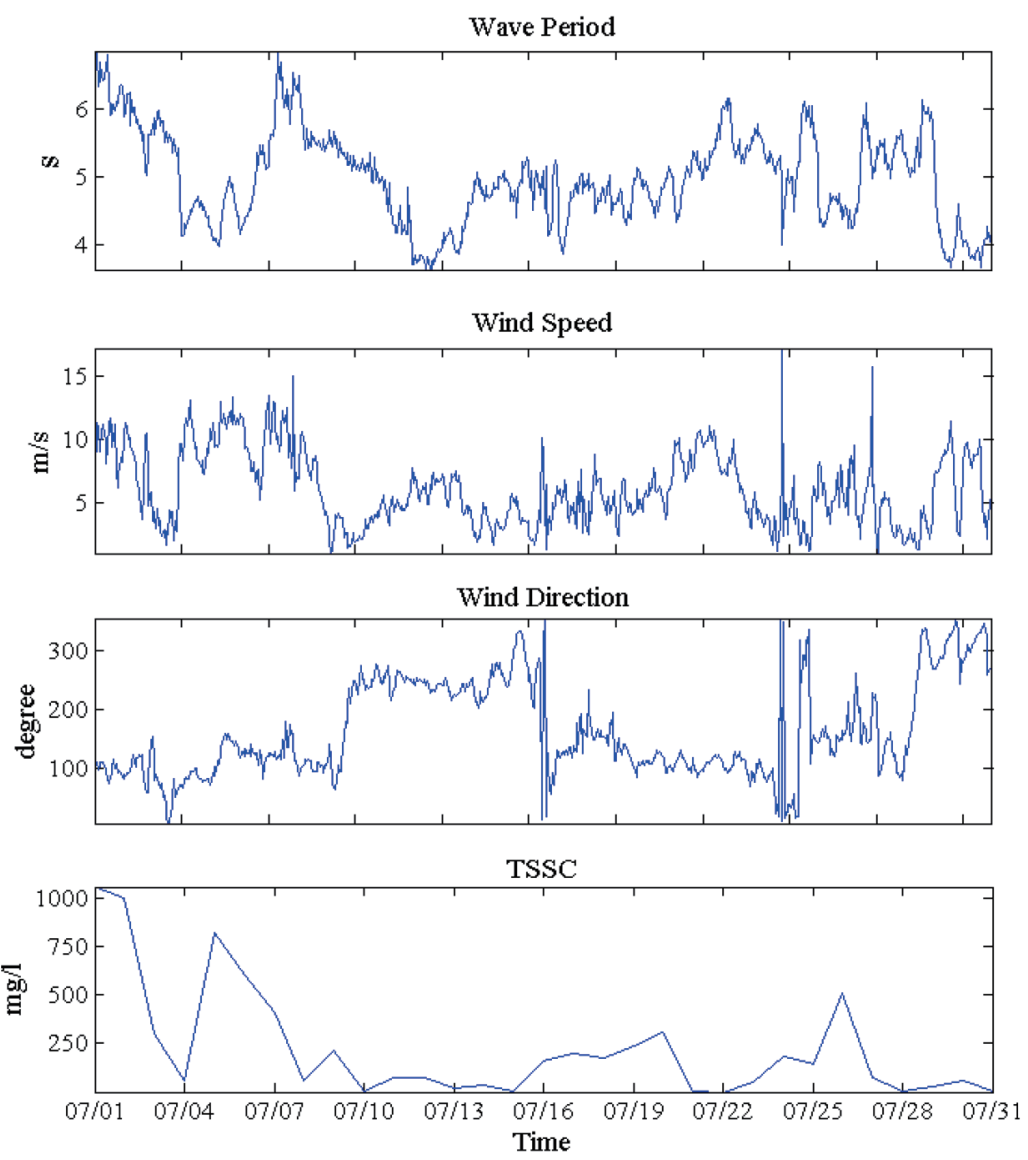

Fig. 2. (Color online) Time series of wave period, wind speed, wind direction, and TSSC in July 2010.

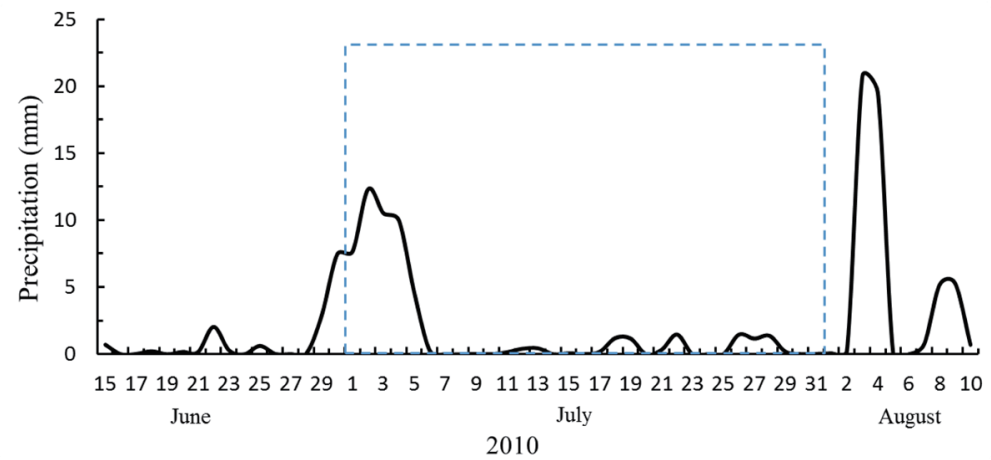

Fig. 3. (Color online) Rainfall variation downstream of Mississippi River between 15 June and 10 August 2010.

\subsection{Collection and processing of satellite imagery}

We used high-resolution remote sensing images to analyze near-shore sediment transport. However, owing to infrequent real-time sampling, this type of imagery is unsuitable for tracing 
TSSC in Terrebonne Bay on a daily timescale. The imagery for this purpose is from NASA's Moderate-resolution Imaging Spectroradiometer (MODIS), which provides daily observational data. The MOD09GQ Version 6 provides an estimate of the surface spectral reflectance of Terra/MODIS $250 \mathrm{~m}$ bands 1-2 corrected for atmospheric conditions, such as gasses, aerosols, and Rayleigh scattering. The daily MODIS Level 2G Terra scene reflectance (MOD09GQ) over Terrebonne Bay was downloaded using Bulk Download Application 1.3.1 (https://www.nasa. gov/) for one month (July 2010). The reflectance data were extracted from MODIS bands 1-2. A total of 31 images were obtained from July 1 to 31, 2010. All images projected into UTM Zone 16N/WGS 84 were radiometrically and geometrically corrected to account for differences in sun and sensor angles as well as atmospheric conditions.

\subsection{TSSC-reflectance model}

Over the past decades, different algorithms have been developed to analyze the concentration of suspended sediment. ${ }^{(31-36)}$ TSSC can be calculated if the ocean-water-leaving reflectance is derived from the remote sensing data. ${ }^{(37,38)}$

Miller and $\mathrm{McKe}^{(34)}$ established the following linear relationship $\left(r^{2}=0.89 ; n=52\right.$; mean square error $(M S E)=4.74)$ between the in situ measurements of TSSC and the atmospherically corrected MODIS Terra band 1 data of the northern Gulf of Mexico:

$$
T S S C=-1.91+1140.25 \times R,
$$

where TSSC is the total suspended sediment concentration and $R$ is MODIS Terra band $1250 \mathrm{~m}$ reflectance data. The linear relationship is consistent over a wide TSSC range measured from nearshore (clear water) stations to Mississippi River plume stations (highly turbid). In addition, this relationship is robust because TSSC was obtained from three different typical systems (i.e., shallow urbanized estuary, coastal embayment, and marginal control by the river system) by three different investigators. ${ }^{(34,39-41)}$ Equation (1) was employed to calculate the TSSC in Terrebonne Bay by using the ENVI band math function.

\subsection{Normalization}

In statistics, the normalization of data means to scale the data to a small specific interval to remove the data unit, transforming data into nondimensional values. It is often used in comparison and evaluation processes. To facilitate the different units or level indices, the normalization of data was carried out. The normalization was in the range between 0 and 1 , which will enable the data to be mapped uniformly $[0,1]$. Suppose the data is in the range of $\left[x^{\min }, x^{\max }\right]$, not $[0,1]$. We want to transform the data into the $[0,1]$ range. Let $x$ be the original value and $x^{*}$ be the normalized value. There are several means to normalize an index. In this study, we use min-max normalization (0-1 normalization), also called dispersion normalization, which is the linear transformation of the original data. Consequently, the results fall into the $[0,1]$ interval and the transformation function is as follows. 


$$
x^{*}=\frac{x-x^{\min }}{x^{\max }-x^{\min }}
$$

If we know the minimum and maximum values of the variable, we can transform the original data into the $[0,1]$ range. If $x=x^{\min }$, then $x^{*}=0$. If $x=x^{\max }$, then $x^{*}=1$. A special case must be taken into consideration to avoid division by zero. If the index is always zero or positive and we know the greatest index, then $x^{\mathrm{min}}=0$ and Eq. (2) can be simplified as

$$
x^{*}=\frac{x}{x^{\max }}
$$

The curve diagram of $x-x^{*}$ is linear and dependent on $x^{\max }{ }^{(42)}$

\section{Results and Discussion}

Suspended particulate matter is mainly derived from particles carried by rivers, atmospheric dust, biological particles generated in the ocean, and weathered material in the crust. The input via rivers and atmosphere mainly depends on the geographical location and weather conditions. The number of biological particles depends on the regulation and supply of nutrients by physical processes such as oceanic circulation and the horizontal mixing of upwellings. Most of the particles carried by rivers settle in estuaries or on the continental shelf; only particles with a sedimentation velocity below $5 \times 10^{3} \mathrm{~cm} / \mathrm{s}$ (diameter less than $5 \mu \mathrm{m}$ ) can be transported into the ocean. The diameter of biological particles is between 1 and $1000 \mu \mathrm{m}$. The suspended particles in the ocean range in size from 1 to $10 \mu \mathrm{m} .{ }^{(43-47)}$ The effect of waves on suspended sediment near the seabed, when the waves spread to shallow water, is to move the seabed sediment. A large amount of sediment suspension or movement will cause a change in the shape of the seabed. Nearshore, waves will break, which will have a considerable destructive effect on the sea bottom and cause a large amount of sediment to be suspended. Most of the erosion and siltation in the beach are concentrated in the fracture zone. It is highly meaningful to study the hydrodynamic characteristic of the breaker zone and to explore the change in suspended sediment concentration near the offshore.

The time series of the measured data in the research period is presented in Fig. 2, which illustrates the changes in wave period, wind velocity, wind direction $2 \mathrm{~m}$ above the sea surface, and TSSC. The highest wave period was $6.84 \mathrm{~s}$ at 1 am on July 1 and the lowest was $3.64 \mathrm{~s}$ at 11 am on July 12. The TSSC, which was extracted from image reflectance, showed a maximum of $1056.47 \mathrm{mg} / 1$ on July 1 and a minimum of $0.83 \mathrm{mg} / 1$ on July 22 .

\subsection{Effects of marine dynamic factors on TSSC}

As particulate matter settles to the seafloor, the surface sediments of the ocean will be resuspended owing to the effects of external forces, such as wind waves, tides, and tidal currents. These never-ending movements exist continuously and are some of the most 
important triggers for the resuspension of seabed sediment, especially in the nearshore area. As the sea surface initially has stable stratification, sufficiently large wind stress at the sea surface will create turbulence that mixes the seawater and then creates a uniform suspended sediment density or a mixed layer. The direction of wind waves, controlled by wind conditions such as wind speed, wind period, and fetch, represents the resuspension capacity. Therefore, changes in various aspects of wind characteristics may affect the resuspension capacity and, thereby, affect the change in TSSC offshore. Rainfall can increase the surface runoff, thus affecting the river sediment content and, hence, the sediment content in the estuary area.

\subsubsection{Effects of river discharge and terrestrial rainfall/runoff}

Usually, in summer, sediment flowing from the river into the sea accumulates mainly in the marine estuarine area, and in winter, it diffuses into a wider and more distant marine area through resuspending processes. In summer, the Mississippi River and terrestrial runoff increase the sediment discharge, and the range of high sediment concentrations in summer is more expansive than that in winter. Figure 3 shows the amount of rainfall near the coast downstream of the Mississippi River from 15 June to 10 August 2010 (the dashed box marks the study period of TSSC).

The Mississippi river as the sediment supplier affects the coastal waters of Terrebonne Bay. The discharge from the Mississippi River system ranges from 200000 to $500000 \mathrm{f}^{3} / \mathrm{s} .{ }^{(48)}$ The sediment load discharged by the Mississippi River system into Terrebonne Bay mostly depends on the rainfall over the land. The rainfall over the land near the Mississippi estuary between 15 June and 10 August 2010 is shown in Fig. 3. The data in Figs. 2 and 3 indicate that the nearshore rainfall has an effect on the TSSC in Terrebonne Bay. It can be seen from Fig. 2 that there are several large peaks of TSSC around 1, 5, and 27 July 2010. Figure 3 shows that heavy rainfall occurred between 28 June and 6 July 2010, with three crest values ( $7.68 \mathrm{~mm}$ on July 1 , $12.32 \mathrm{~mm}$ on July 2, and $10.0 \mathrm{~mm}$ on July 4). Because of the lagging and accumulation effect of rainfall on the sediment discharge from the river, rainfall contributes to the peak values of the sediment concentration on July 1 and 5, 2010. It can be seen in Fig. 2 that TSSC exhibited a peak of about $1056.47 \mathrm{mg} / \mathrm{l}$ on July 1 . In addition, three rainfall processes occurred on 17-19, 22, and 26-28 July, and the corresponding rainfall peaks were $1.2 \mathrm{~mm}$ (18 July), $1.46 \mathrm{~mm}$ (22 July), and $1.45 \mathrm{~mm}$ (26 July), respectively. In addition, TSSC attains peaks with the values of $308.24 \mathrm{mg} / \mathrm{l}$ (20 July), $182.01 \mathrm{mg} / \mathrm{l}$ (24 July), and $505.96 \mathrm{mg} / \mathrm{l}$ (26 July). We found that there was a certain delay in the response of suspended sediment concentration to rainfall over the area. From the above analysis results, we conclude that rainfall runoff in the Mississippi River Basin affects the TSSC in the southern part of Terrebonne Bay.

\subsubsection{Effect of wave period on TSSC}

Wind wave, tide, and tidal current ultimately act on the bottom bed through waves or currents. The wave action significantly increases the bottom shear stress of the offshore seabed, 
and the shear action of the current results in a large amount of sediment being resuspended over the seabed. At the same time, as a result of the disturbance by waves, the water body is vertically mixed and the high concentration of suspended mud at the lower depths can reach the surface water body. Once the seabed sediment enters the water body, the strong turbulence caused by waves decreases and the sediment can be transported over long distances by tidal and residual currents.

Wave oscillations can cause the mixing of surface and subsurface waters in the coastal region. Sediment particles will settle owing to the effect of gravity, and the sediment will be transported to other places by coastal current, resulting in the reduction in its concentration at the sea surface. During periods of relatively calm waves, the wave period is higher and the turbulence intensity is lower. Then, the sedimentation velocity of the sediment under gravity is greater than that of the sediment moved by the shear force of the flow bed (on the macroscopic level), causing the suspended sediment concentration to be lower on the surface.

Figure 2 shows that when the wave period increases (relatively calm waves), TSSC decreases correspondingly; TSSC is inversely related to the wave period. During the period from July 5 to 7 , TSSC was maximum on July $5(820.55 \mathrm{mg} / \mathrm{l})$; at the same time, the wave period was minimum (about $4 \mathrm{~s}$ ). On July 8 , TSSC was very low $(60.35 \mathrm{mg} / \mathrm{l})$ and the wave period was greater $(6 \mathrm{~s})$. From July 10 to 15 , TSSC increased and then decreased as the wave period decreased and then increased, respectively. The variations in TSSC and wave period from July 26 to 31 were similar to those in the first three periods. The peak TSSC was $505.96 \mathrm{mg} / 1$ and the wave period was about $4.2 \mathrm{~s}$ on July 26 . The observational analysis (in most of the cases) revealed that TSSC and wave period have an inverse relationship in Terrebonne Bay.

\subsubsection{Effect of wind speed on TSSC}

The atmosphere exerts a direct force on the sea surface through the buoyancy (heat and freshwater) exchange and sea surface wind stress. Wind-induced waves enhance the bottom shear stress and cause seabed turbulence, which can cause sediment resuspension and the tidally transported sediment to remain in suspension. Wind (speed and direction) has a strong effect on the trajectory, diffusion velocity, and diffusion range of suspended sediment. ${ }^{(4)}$ Particularly in the shallow water near the shore, the direction of sediment transport varies with wind speed and wind direction, whereas the direction of sediment transport in the deep sea is essentially fixed. ${ }^{(50)}$

As can be seen in Fig. 2, the variation trends of TSSC and wind speed are similar; when the wind speed increases or decreases, TSSC, after a slight delay, also increases or decreases. This response of TSSC to the wind speed is clear in three time periods. First, at 11 am on July 3, the wind speed showed a trough of $1.73 \mathrm{~s}$, followed by a peak of about $15.05 \mathrm{~s}$ at $9 \mathrm{pm}$ on July 7. During this process, TSSC, after a slight delay, reached a trough of $56.93 \mathrm{mg} / \mathrm{l}$ on July 4 , then crested between July 4 and 8 , showing a maximum of $820.55 \mathrm{mg} / 1$ on July 5 . In the second period, there was a slow increase in wind speed from July 16 to 22 with a maximum of $11.09 \mathrm{~s}$ at 6 am on 22 July. Similarly, TSSC increased accordingly, and its peak was $308.24 \mathrm{mg} / 1$ on 20 
July. In the third period, there was strong wind at $6 \mathrm{pm}$ on 24 July with a maximum of $17.26 \mathrm{~s}$, and the delayed TSSC response showed a peak of $505.96 \mathrm{mg} / \mathrm{l}$ on 26 July. The results of the above analysis confirmed a clear effect of wind speed on TSSC in the study area.

\subsubsection{Effect of wind direction on TSSC}

Wind direction is also an important factor affecting TSSC. Wind direction is defined as the direction from which wind comes, clockwise being positive. $0^{\circ}$ and $360^{\circ}$ mean a north wind $(\mathrm{N})$, $0^{\circ}$ to $90^{\circ}$ indicate a northeast wind (NE), $90^{\circ}$ an east wind (E), $90^{\circ}$ to $180^{\circ}$ a southeast wind (SE), $180^{\circ}$ a south wind (S), $180^{\circ}$ to $270^{\circ}$ a southwest wind (SW), $270^{\circ}$ a west wind (W), and $270^{\circ}$ to $360^{\circ}$ a northwest wind (NW). Table 1 shows hourly and daily frequencies of wind direction.

At the station location, the shoreward wind (S, SW, and SE) is mainly southerly, while the offshore wind (including N, NW, and NE) is mainly northerly. Hourly wind directions were used to calculate the frequencies in different directions for July 2010. As can be seen from Table 1, the main wind direction was SE, which is southerly, with a frequency of $49.60 \%$ (hourly). In addition, secondary wind directions were SW and NE, with frequencies of 22.04 and 13.98\% (hourly), respectively. The frequencies of other wind directions were lower. According to the measured hourly wind directions in July 2010, the strongest wind in this area was in the NE direction $\left(58^{\circ}\right)$, the maximum wind speed being $17.26 \mathrm{~m} / \mathrm{s}$ at $6 \mathrm{pm}$ on $24 \mathrm{July}$. The direction of the next-strongest wind was SW $\left(228^{\circ}\right)$, where the wind speed was $15.79 \mathrm{~m} / \mathrm{s}$ at $8 \mathrm{pm}$ on 27 July. Figure 2 shows that from July 5 to 9, there was wind of higher intensity mainly from the southeast, whereby particulate matter was lifted by wind and waves, then transported by tidal current, resulting in an increase in TSSC over the coastal areas. If only the effect of wind direction on TSSC is considered, TSSC in Terrebonne Bay is mainly controlled by onshore wind, which accounts for $72.04 \%$ of hourly wind direction, because the generated waves occurred due to different wind directions. The study area is the nearshore, the onshore wind time is longer than the offshore wind time, and the continuous offshore wind tends to generate large wind waves. Most of the waves are caused by sea wind, which creates waves when it comes in contact with the sea away from the shore. Onshore wind can also create waves, but the waves are in the same direction as the wind. Therefore, the wind blows behind the waves, creating a bit of a spray. Offshore wind blows against waves formed in the opposite direction and fixes their shape, making them longer. However, the offshore wind frequency is lower than the onshore wind frequency, which limits its ability to raise high waves in the study area. The amount of suspended sediment in the coastal water is affected by onshore wind and waves, and the suspended sediment is transported and deposited along the coast by flood and ebb currents. The onshore wind direction is SE, and the hourly frequency of the SE wind direction accounts for $49.6 \%$, which not only causes the erosion of the shoreline by wind, but also brings the

Table 1

Frequencies of wind directions in Terrebonne Bay in July 2010 (\%).

\begin{tabular}{llllllllr}
\hline Wind direction & N & NE & E & SE & S & SW & W & NW \\
\hline Frequency (Hour) & 0 & 13.98 & 1.21 & 49.60 & 0.40 & 22.04 & 0.13 & 12.63 \\
Frequency (Daily) & 0 & 12.90 & 0 & 58.06 & 0 & 22.58 & 0 & 6.45 \\
\hline
\end{tabular}


sediment from Timbalier Bay in the turbidity zone to the nearshore and increases the nearshore TSSC. Timbalier Bay is located in the nearshore turbidity zone northeast of the research area, where a large amount of sediment is suspended and deposited.

Hourly wind speeds were determined for each direction, and the average wind speed in each direction was calculated and is presented in Fig. 4. It can be seen from the graph that the mean wind speed is maximum $(13.88 \mathrm{~m} / \mathrm{s})$ when the wind direction is northeast $\left(58^{\circ}\right)$. In this direction, there are two other high mean wind speeds, 12.03 and $11.35 \mathrm{~m} / \mathrm{s}$ in the directions of 81 and $73^{\circ}$, respectively. There are two other high mean wind speeds, 11.64 and $11.03 \mathrm{~m} / \mathrm{s}$, for the southeast $\left(159^{\circ}\right)$ and northwest $\left(329^{\circ}\right)$ directions, respectively. The minimum average wind speed of each direction is $1.53 \mathrm{~m} / \mathrm{s}$ in the southwest $\left(210^{\circ}\right)$ direction. Three other low mean wind speeds of $1.68,1.75$, and $1.83 \mathrm{~m} / \mathrm{s}$ are also in this direction $\left(235,220\right.$, and $205^{\circ}$, respectively). The average wind speed in the northwest $\left(291^{\circ}\right)$ direction is $1.72 \mathrm{~m} / \mathrm{s}$.

The hourly wind direction of each day was averaged to determine the daily wind direction: the NE direction on 4 days accounts for $12.90 \%$, the SE direction on 18 days accounts for $58.06 \%$, the SW direction on 7 days accounts for $22.58 \%$, and the NW direction on 2 days accounts for $6.45 \%$. The details are given in Table 1 .

Figure 5 shows the mean daily variations in TSSC and wind direction in July 2010. As

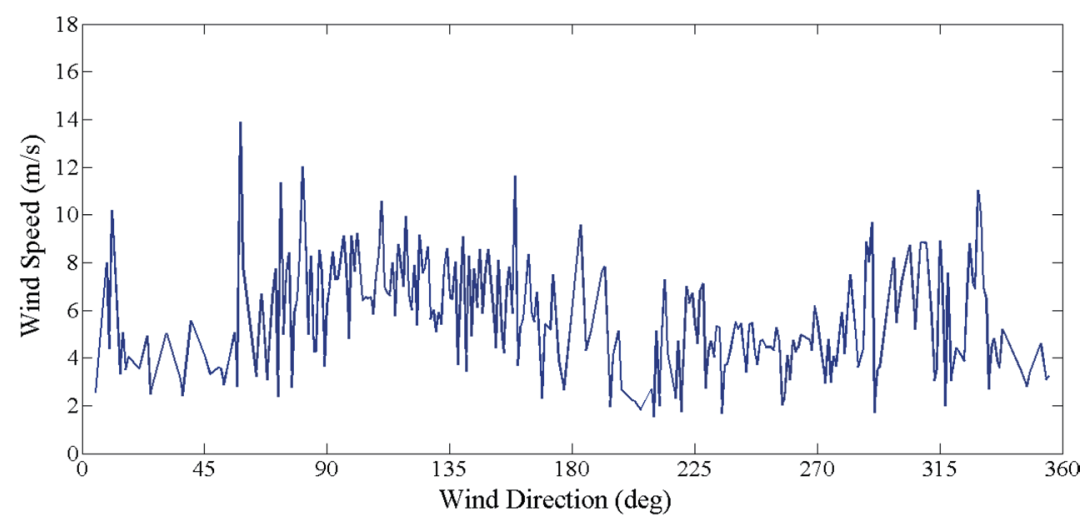

Fig. 4. (Color online) Average wind speed for each direction in Terrebonne Bay in July 2010.

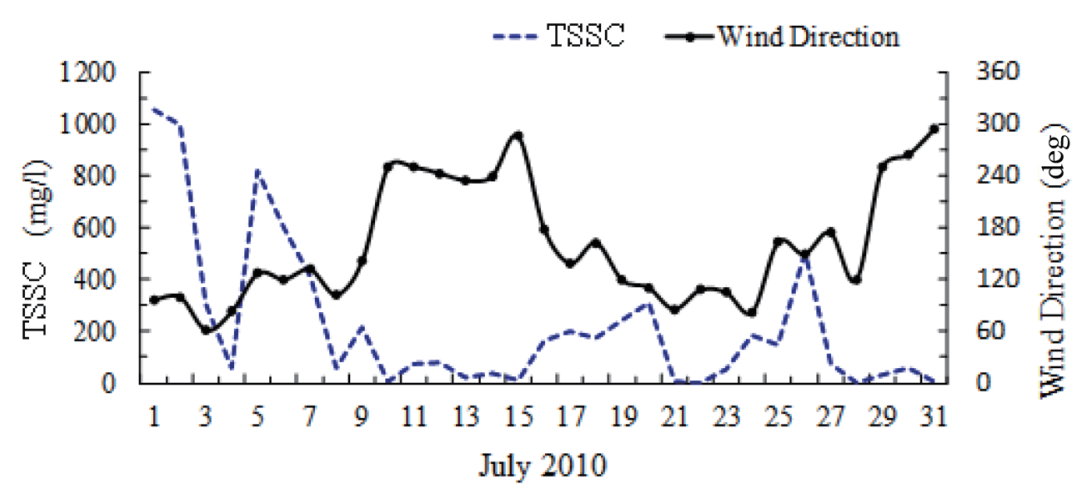

Fig. 5. (Color online) TSSCs in different wind directions in Terrebonne Bay in July 2010. 
can be seen from Fig. 5, on July 1, the maximum TSSC of $1056.47 \mathrm{mg} / 1$ was observed in the southeast $\left(96.75^{\circ}\right)$ direction. Three high TSSCs of 994.56, 820.55, and $605.27 \mathrm{mg} / 1$ were observed on July 2, 5, and 6, along the wind directions of 99.63, 127.33, and $120.17^{\circ}$, respectively. The minimum TSSC of $0.83 \mathrm{mg} / 1$ corresponds to the southeast $\left(107.79^{\circ}\right)$ direction, observed on July 22 . Three other small values $(1.05,3.68$, and $4.59 \mathrm{mg} / \mathrm{l})$ were found in the directions of $118.92,85.58$, and $293.96^{\circ}$ on July 28,21 , and 31, respectively.

As seen in Fig. 5, between July 1 and 7, but except July 4, and on July 9, TSSCs were relatively high, and the wind direction was SE, except for July 3 (wind direction is NE). In contrast, TSSC was low from July 10 to 15 , and the wind direction was SW, except on July 15 (NW). From July 16 to 20 and 25 to 26, the wind direction was SE and TSSC was higher. TSSC was lower between July 27 and 31, and the wind directions were SE (27 and 28), SW (29 and 30), and NW (31).

In summary, when the wind direction was SE, TSSC increased in most cases (13 days: increase, 5 days: decrease) in the study area in July 2010. In the study site near the extended part of Timbalier Bay, located in the estuarine turbidity zone, much particulate matter was present. When the wind direction was SE, the wind transported the sediment and particulate from the seashore into nearshore water, leading to an increase in TSSC over the study area. When the wind direction was SW, TSSC decreased (7 days) in this direction owing to wind action. A large amount of clear water came from the open sea to the nearshore and diluted the sediment and particulate such that TSSC decreased in the surface water. When the wind direction was NW, TSSC decreased (2 days), as was also the case for the SW direction. When the wind direction was NE, TSSC could not be determined (2 days: increase, 2 days: decrease).

\subsubsection{Comprehensive effect of various factors}

On July 1, the amount of surface sediment was high owing to river discharge and terrestrial runoff as a result of prior rainfall (between June 28 and July 5) over the land. Rainfall over the land can result in a high TSSC on the sea surface because of terrestrial discharge; however, a low TSSC can be observed in other periods.

It was found that with an increase in wave period, TSSC decreased. When a wave approaches the coast, if the wave height is more than the depth and the height ratio reaches 1/7 or more, the wave will break in the surf zone. Breaking waves disturb the sea bottom and the sediment will be suspended in the water. Mixing occurs over the coastal region owing to a higher amplitude of waves. Because of oscillatory current produced by waves, mixing occurs between surface and subsurface waters. When the wave period is small, the mixing of water due to waves is confined to smaller depths, which results in an increase in TSSC in surface water.

TSSC mainly depends on the terrestrial rainfall/runoff, wave height, wind speed, and wind direction in Terrebonne Bay. Terrestrial runoff increases TSSC, whereas a higher wave period results in a lower TSSC in surface water. As a wave moves towards the coast, it breaks and an upper flushing flow and backflow will be formed at the same time. An important cause of the increase in the amount of suspended matter is upper flushing flow, especially where the wave has broken. When a stable wave condition is maintained for a long time, the sediment 
concentration will remain stable. Wind direction is also an important factor affecting the sediment concentration in surface water. Nearshore TSSC varies with wind direction. TSSC is relatively high with onshore wind (SE), but low with offshore wind (NW). Wind speed affects the size and distribution of sediment in the sea area, and the overall trend is an increase with increasing wind speed.

\subsection{Relationship between TSSC and marine dynamic factors in Terrebonne Bay}

To study the relationship between TSSC and marine dynamic factors more clearly, normalization was carried out (Figs. 6 and 7). In this study, we used the probability distribution to normalize the marine dynamic factors (wave period and wind speed) and TSSC.

Figures 6 and 7 show the close relationships between TSSC and two factors. The correlation coefficients of wave period and wind speed with TSSC were 0.45 and 0.47 , respectively, which exceeded the $99 \%$ significance level. The correlation with wind speed was higher. The resuspension process caused by wind agitation affects the change in TSSC over the study area on this time scale (one month). TSSC exhibits a corresponding delay in its response to marine dynamics, which affects their correlation.

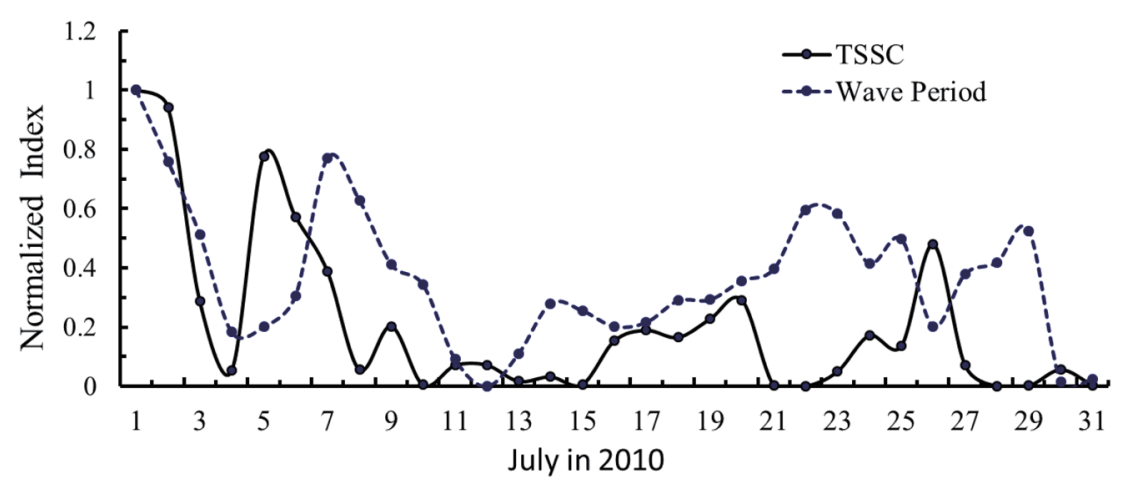

Fig. 6. (Color online) Relationship between TSSC and wave period in Terrebonne Bay.

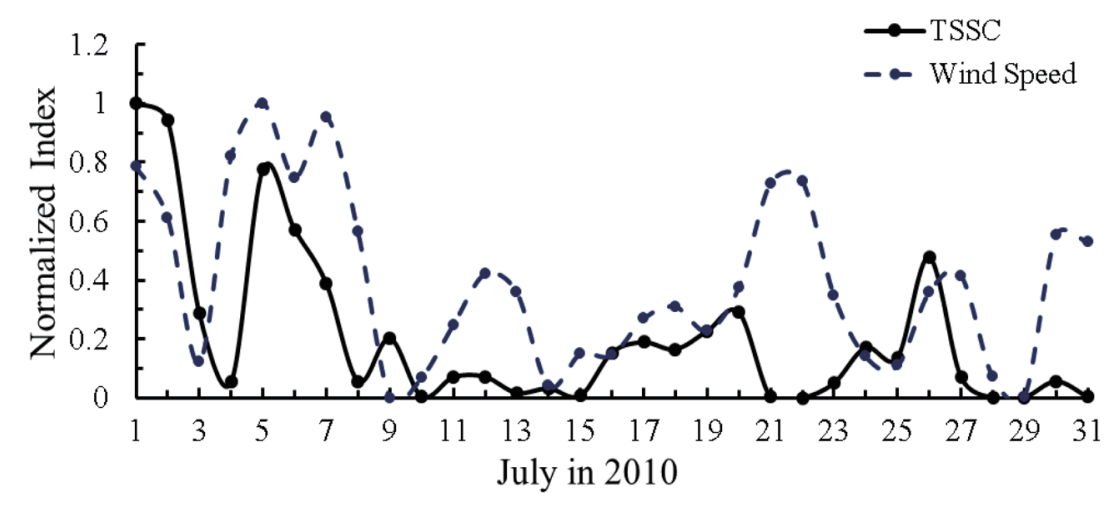

Fig. 7. (Color online) Relationship between TSSC and wind speed in Terrebonne Bay. 


\subsubsection{Relationship between TSSC and wave period}

Waves, as one of the active factors of marine dynamics, play an important role in the evolution of sediment in the Mississippi Delta. The main reason for the increase in TSSC under wave action is wave and seabed interaction, i.e., waves form as a vortex (oscillatory currents) with sediment at the seabed boundary layer, whereby the sediment enters the water body from the seabed toward the surface. The magnitude of the wave period reflects the frequency of wave change. The energy contained in a wave is called wave energy, which is related to the wave height and period. The wave cycle is related to the topography and wind speed. The magnitude of the wave period has an important effect on sediment resuspension and migration. The normalized wave period and TSSC were studied to find the relationship between them.

Figure 6 illustrates the variations in normalized TSSC (solid line) and wave period (dashed line). It is seen that the wave period has a significant effect on the change in TSSC after July 4 (because of the heavy rainfall between June 28 and July 4). When the normalized index of the wave period increases (higher wave period), the amount of mixing between surface and subsurface waters decreases. Moreover, TSSC decreases, as can be seen in Fig. 6. On July 5, a low wave period (0.20) and a high TSSC (0.777) can be observed. Also, we can see some peak and trough values: for example, the wave period normalization index was at a peak (0.597) and the TSSC normalized index was at a low (0) on July 22; the wave period was at a low (0.202) and TSSC was at a peak (0.479) on July 26; and the wave period was at a peak (0.525) and TSSC was at a trough (0.002) on July 29. In most cases, the wave period increased and TSSC decreased, and vice versa in Terrebonne Bay in July 2010.

\subsubsection{Relationship between TSSC and wind speed}

Seabed turbulence will be enhanced by wave action and bottom shear stress, leading to sediment resuspension. Wind is an important factor for TSSC and sediment resuspension. ${ }^{(51-53)}$ The wind causes the variation of waves. The oscillatory currents produced by waves mix the surface and subsurface waters, thereby changing the spatial distribution of TSSC. The sediment concentration increases notably during spring and summer months owing to the increased onshore wind speed and direction. During late spring and summer when wind speed is the greatest, turbidity and sediment concentrations increase.

The passage of cold fronts plays a significant role in coastal processes over the northern Gulf of Mexico. ${ }^{(27,54-56)}$ Water flushing is another phenomenon associated with the passage of a cold front from Louisiana Bay to the Gulf of Mexico. The flushing rate mainly depends on the wind direction with respect to geometry and wind speed. A northwest wind is the most effective and causes $40 \%$ of the bay water to be flushed out. ${ }^{(56)}$

Figure 7 illustrates the variations in normalized TSSC (solid line) and wind speed (dashed line), which analyze to findout the relationship between them. TSSC is seen to be closely related to the wind speed; TSSC increases with wind speed. However, TSSC exhibits a delay in its response to wind speed and also depends on rainfall. The lag was about one day before 4 July, and during 5 to 8 July, the variations in both wind speed and TSSC were almost the same, 
and there was almost no rainfall in this period, except on 5 July. The lag of TSSC in response to wind speed was about one day on 9 July. From 10 to 14 July, there was no lag between wind speed and TSSC. However, a one-day lag was observed from 15 to 17 July. The response of TSSC to wind speed showed a two-day lag between 18 to 23 July, and this trend remained almost the same after July 24. There were several small rainfall events during July 11 to 29 , which also affected the change in TSSC, so the response of TSSC to the marine dynamic factors became complex in this period. From the results of the above analysis, the mechanism behind the effect of resuspension caused by wind agitation on the change in TSSC is recognized to be complex. In this process, rainfall has some effect on TSSC.

\section{Conclusion}

A large amount of land has been lost in Terrebonne Bay owing to coastal erosion caused by waves, wind, and rainfall. The suspended matter in this region mainly originates from the erosion of the coast, resuspension from the seabed, discharge from the Mississippi River, and terrestrial rainfall/runoff. In this study, TSSC was retrieved from MODIS remote sensing data, and we focused on the changes in TSSC driven by rainfall, waves, and wind.

The results demonstrated that marine dynamic factors clearly affect the spatial distribution of TSSC. Rainfall leads to erosion and increased river discharge, whereby particles are transported to the estuary and coast. Heavy rainfall had a significant effect on TSSC in early July 2010.

Wind and waves are the main dynamic factors affecting the spatial distribution of TSSC. With increasing wind speed, agitation between the sea surface and the bottom increases causing the seabed sediment to enter into the water, leading to an increase in suspended sediment concentration, which raises to the surface. Through erosion, coastal sediments are introduced into surface water, increasing the concentration of suspended matter at the sea surface. There is a close relationship between TSSC and wind speed, although there is a certain lag. The onshore wind (SE) has an important effect on TSSC. This effect is complex; in most cases, TSSC is inversely proportional to the wave period.

\section{Acknowledgments}

This study was supported by the National Natural Science Foundation of China (Grant Nos. 51479179 and 51579230), the Science Foundation of Zhejiang Ocean University (Grant No. 21105011713), State Key Laboratory of Plateau Ecology and Agriculture, Qinghai University (Grant No. 2018-KF-02), and China Scholarship Council (Grant No. 201508330709).

\section{Competing Interests}

The authors declare no competing interests. 


\section{References}

1 J. E. Harris: Deep Sea Res. 24 (1977) 1055. https://www.sciencedirect.com/journal/deep-sea-research/vol/24/ issue $/ 11$

2 B. D. Ache, K. Bylsma, C. Crossett, and A. David: Gulf of Mexico at a Glance. National Ocean Service/NOAA/U.S. Department of Commerce, Washington, D.C. (2008) 8-22. https://aamboceanservice.blob.core.windows.net/ oceanservice-prod/deepwaterhorizon/gulf_glance_1008.pdf

3 A. Palanques, X. D. de Madron, P. Puig, J. Fabres, J. Guillén, A. Calafat, M. Canals, S. Heussner, and J. Bonnin: Mar. Geol. 234 (2006) 43. https://doi.org/10.1016/j.margeo.2006.09.002

4 P. Larcombe, P. V. Ridd, A. Prytz, and B. Wilson: Coral Reefs 14 (1995) 163. https://doi.org/10.1007/ BF00367235

5 A. R. Orpin, P. V. Ridd, and L. K. Stewart: Aust. J. Earth Sci. 46 (1999) 883. https://doi.org/10.1046/j.14400952.1999.00751.x

6 D. Kobashi, F. Jose, and G. Stone: Gulf Coast Assoc. Geol. Soc. Trans. 56 (2006) 395.

7 F. C. Wang, T. Lu, and W. B. Sikora: J. Coast. Res. 9 (1993) 209.

8 D. H. Schoellhamer: Estuarine Coastal Shelf Sci. 40 (1995) 603. https://doi.org/10.1006/ecss.1995.0041

9 J. G. Booth, R. L. Miller, B. A. McKee, and R. A. Leathers: Continental Shelf Res. 20 (2000) 785. https://doi. org/10.1016/S0278-4343(00)00002-9

10 P. Y. Sheng and W. Lick: J. Geophys. Res. 84 (1979) 1809. https://doi.org/10.1029/JC084iC04p01809

11 F. B. Halper and D. W. McGrail: Continental Shelf Res. 8 (1988) 23. https://doi.org/10.1016/02784343(88)90022-2

12 M. S. Longuet-Higgins: J. Geophys. Res. 75 (1970) 6778. https://doi.org/10.1029/JC075i033p06790

13 Q. Chen, J. T. Kirby, R. A. Dalrymple, F. Shi, and E. B. Thornton: J. Geophys. Res. 108 (2003) 3362. https:// doi.org/10.1029/2002JC001308

14 B. D. Johnson and J. M. Smith: J. Geophys. Res. 110 (2005) C06006. https://doi.org/10.1029/2004JC002336

15 R. A. Schwimmer: J. Coastal Res. 17 (2001) 672. https://doi.org/10.1016/j.csr.2009.08.018

16 M. Marani, A. D’Alpaos, S. Lanzoni, and M. Santalucia: Geophys. Res. Lett. 38 (2011). https://doi. org/10.1029/2011GL048995

17 R. R. Twilley, S. J. Bentley Sr., Q. Chen, D. A. Edmonds, S. C. Hagen, N. S.-N. Lam, C. S. Willson, K. Xu, D. W. Braud, R. H. Peele, and A. McCall: Sustainability Sci. 11 (2016) 711. https://doi.org/10.1007/s11625-016-03744

18 A. Karimpour, Q. Chen, and R. R. Twilley: Sci. Rep. 7 (2017) 40654. https://doi.org/10.1038/srep40654

19 J. C. Ritchie, P. V. Zimba, and J. H. Everitt: Photogramm. Eng. Remote Sens. 69 (2003) 695.

20 D. G. Bowers and C. E. Binding: Estuarine Coastal Shelf Sci. 67 (2006) 219. http://doi.org/10.1016/ j.ecss.2005.11.010

21 D. G. Bowers, C. E. Binding, and K. M. Ellis: Estuarine Coastal Shelf Sci. 73 (2007) 457. http://doi. org/10.1016/ j.ecss.2007.02.005

22 E. M. M. Novo, J. D. Hansom, and P. J. Curran: Int. J. Remote Sens. 10 (1989) 1283. http://doi. org $/ 10.1080 / 01431168908903967$

23 J. C. Ritchie, F. R. Schiebe, and R. McHenry: Photogramm. Eng. Remote Sens. 69 (1976) 695.

24 P. J. Curran and E. M. M. Novo: J. Coastal Res. 4 (1988) 351.

25 N. N. Rabalais, R. E. Turner, and D. Scavia: BioScience 52 (2002) 129.

26 T. J. Schmugge, W. P. Kustas, J. C. Ritchie, T. J. Jackson, and A. Rango: Adv. Water Resour. 25 (2002) 1367. https://doi.org/10.1016/S0309-1708(02)00065-9

27 D. A. Pepper and G. W. Stone: Mar. Geol. 210 (2004) 43. https://doi.org/10.1016/j.margeo.2004.05.004

28 T. O. Everett: Louisiana State University Master's Thesis (2016) 4514. https://digitalcommons.lsu.edu/ gradschool theses $/ 4514$

29 R. P. Kyle: Louisiana State University Master's Thesis (2014) 4125. https://digitalcommons.1su.edu/gradschool theses/4125

30 A. Karimpour, Q. Chen, and R. Jadhav: Sediment Transport, A. K. Abdul and W. Wu, Eds. (Nova Science Publishers, Inc., New York, 2013) Chap. 11, p. 339. ISBN: 978-1-62618-683-5.

31 R. P. Bukata, J. H. Jerome, A. S. Kondratyev, and D. V. Pozdnyakov: Optical Properties and Remote Sensing of Inland and Coastal Waters (CRC Press, Boca Raton, 1995) p. 8. ISBN: $9780849347542-$ CAT\# 4754.

32 E. J. D'Sa, R. L. Miller, and B. A. McKee: Geophys. Res. Lett. 34 (2007). https://doi. org/10.1029/2007GL031192

33 A. G. Dekker, R. J. Vos, and S. Peters: Int. J. Remote Sens. 23 (2002) 15.

34 R. L. Miller and B. A. Mckee: Remote Sens. Environ. 93 (2004) 259. https://doi.org/10.1016/j.rse.2004.07.012 
35 R. P. Stumpf and J. Pennock: J. Geophys. Res. 94 (1989) 14363. https://doi.org/10.1029/JC094iC10p14363

36 J. Shen, H. Tan, J. Wang, and J. Wang: J. Internet Technol. 16 (2015) 171.

37 G. McPherson: Applying and Interpreting Statistics: A Comprehensive Guide 640 (Springer, New York, 2001) 2nd ed., p. 640. ISBN: 9781441928795.

38 F. R. Schiebe, J. A. Harrington Jr., and J. C. Ritchie: Int. J. Remote Sens. 13 (1992) 1487. https://doi. org/10.1080/01431169208904204

39 Z. Chen, C. Hu, and F. Muller-Karger: Remote Sens. Environ. 109 (2007) 207. https://doi.org/10.1016/ j.rse.2006.12.019

40 F. Lahet and D. Stramski: Remote Sens. Environ. 114 (2010) 332.

41 M. Zhang, J. Tang, Q. Dong, Q. Song, and J. Ding: Remote Sens. Environ. 114 (2010) 392. https://doi. org/10.1016/j.rse.2009.09.016

42 K. Teknomo: Similarity Measurement (2015). http: $\backslash$ people.revoledu.com/kardi/tutorial/Similarity/ Normalization.html\#Statistic

43 R. H. Meade: J. Geol. 90 (1982) 235. https://doi.org/10.1086/628677

44 V. Ramaswamy, R. R. Nair, S. Manganini, B. Haake, and V. Ittekkot: Deep Sea Res. 38 (1991) 169. https://doi. org/10.1016/0198-0149 (91)90078-T

45 M. Alber: Estuarine Coastal Self Sci. 50 (2000) 805. https://doi.org/10.1006/ecss.1999.0610

46 R. J. Gibbs, D. M. Tshudy, L. Konwar, and J. M. Martin: Sedimentology 36 (1989) 987. https://oi.org/10.1111/ j.1365-3091.1989.tbo1536.x

47 A. Turner and G. E. Millward: Estuarine Coastal Shelf Sci. 55 (2002) 857. https://doi.org/10.1006/ ecss.2002.1033

48 S. L. Postel, J. I. Morrison, and P. H. Gleick: Water Int. 23 (1998) 119. https://doi. org/10.1080/02508069808686757

49 S. Li, Y. Wang, H. Huang, and D. Chen: J. Waterway Harbor 36 (2015) 297 (in Chinese). https://doi. org/10.3969/j.issn.1005-8443.2015.04.004

50 S. Zou and M. Lin: Prog. Geophys. 22 (2007) 273 (in Chinese).

51 R. B. Krone: San Francisco Bay: The Urbanized Estuary (California Academy of Sciences, San Francisco, 1979) p. 85.

52 D. H. Schoellhamer: J. Geophys. Res. 101 (1996) 12087.

53 A. Brand, J. R. Lacy, K. Hsu, D. Hoover, S. Gladding, and M. T. Stacey: J. Geophys. Res. 115 (2010) 1. https:// doi.org/10.1029/2010JC006172

54 P. L. Chaney and G. W. Stone: Shore Beach 64 (1996) 27.

55 G. W. Stone and P. Wang: Gulf Coast Assoc. Geol. Soc. Trans. 49 (1999) 478.

56 Z. Feng and C. Li: J. Mar. Syst. 82 (2010) 252. https://doi.org/10.1016/j.jmarsys.2010.05.015 